\title{
The influence of Islamic religiosity on e-book piracy: an accounting student perspective
}

\author{
Dela Anggraeni, Muamar Nur Kholid \\ Department of Accounting, Faculty of Business and Economics, Universitas \\ Islam Indonesia, Yogyakarta, Indonesia \\ *Corresponding author: muamar.nk@uii.ac.id
}

\author{
Article History \\ Received, 25 October 2020 \\ Revised 1, 7 November 2020 \\ Revised 2, 12 November 2020 \\ Accepted, 15 November 2020
}

\begin{abstract}
Purpose: This study aims to examine the determinant factors affecting accounting student's intention to carrying out e-book piracy.
\end{abstract}

Methodology: This study used quantitative method with primary data through questionnaire from 187 selected students as samples. The data were analyzed using the PLS SEM supported by SmartPLS software.

Findings: The findings of the analysis showed that attitude significantly affects the intention of carrying out E-book piracy while Islamic religiosity negatively influences the intention of carrying out E-book piracy. The findings of this study contribute to the literature regarding piracy in general and e-book piracy in particular.

Practical implications: The present study also has implications for higher education institution especially for accounting study program to formulate strategies to minimize e-book piracy by accounting students

Originality: This study integrates Islamic religiosity in a research model which is rarely done in the context of research on e-book piracy by accounting students

Keyword: Islamic Religiosity, Attitude, self-efficacy, E-book Piracy, Accounting.

Cite this article:

Anggraeni, D. \& Kholid, M. N. (2020). The influence of Islamic religiosity on ebook piracy: An accounting student perspective. Asian Joumal of Islamic Management, 2(2), 96-106. https://doi.org/10.1108/AJIM.vol2.iss2.art3

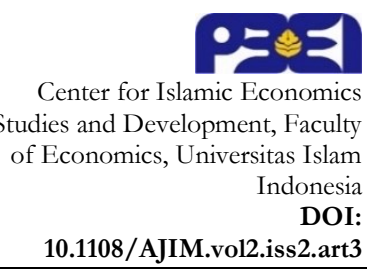

\section{Introduction}

In Indonesia, there are many fraud cases involving accountant profession. Some of them are financial statement modifications by Bukopin Bank which resulted in an unnatural increase in credit and commission-based income (Banjarnahor, 2018), and mismatch of audit results in PT Sunprima Nusantara Financing conducted by the auditors and the Financial Services Authority (Syafina, 2018). Moreover, various frauds were also committed by accountants around the world when they were students. Research conducted by Nonis and Swift (2001) found that students who behave dishonestly while in college will tend to do the same thing when they work.

E-book piracy is one of the most common frauds in Indonesian education field. Furthermore, book piracy is also a global problem that threatens the existence of publishers (Kozlowski, 2018). Statistical data shows that in Russia, 92 percent of book readers illegally download books from the internet (Kozlowski, 2018). This phenomenon also happens in Indonesia. In fact, Indonesia ranks as one of the most countries with the worst Intellectual Property Rights (IPR) protection according to Political and Economic Risk Consultacy (PECR) data (Sukria, 
2019). There is no clear data on how many books were pirated. However, the fact that there are many sales of pirated books both offline and online in Indonesia, it can be concluded that book piracy in Indonesia has reached a worrying level (Sukria, 2019). In addition, considering that the book procurement process is very long and involves many types of work, such as writers, editors, publishers, and cover designers, the practice of book piracy can be considered as a huge loss to many parties. For instance, Balai Pustaka publisher has lost IDR 125 billion due to the practice of book piracy (Bangai, 2019). It is not only the publishers who suffered loss, but also the authors got disadvantage. Theauthors lost their income from royalties from the book industry process (Syambudi, 2019). In conclusion, it is clear that apart from violating Intellectual Property Rights, the practice of book piracy can also harm many types of jobs in the book industry.

Above all, it is important to find out the factors that influence accounting students to conduct and use pirated e-books. Several previous studies have conducted research. Research on students in China states that the variables in the Theory of Planned Behavior (TPB), namely attitude, subjective norms, and perceived behavioral control can influence individual intentions to commit digital piracy (Yoon, 2011). Different results were shown on students in South Korea which subjective norms does not influence individual intentions to commit digital piracy (Yoon, 2012). The variables in the TPB theory that have an influence on individual intentions to commit digital piracy are only attitude and perceived behavioral control. Research in Indonesian context also found that moral obligation, self-efficacy, subjective norms, and facilitating conditions have a significant effect on the intention to pirate digital books (Hati et al., 2019). Although there have been several studies in the context of e-book piracy, there are still few studies that try to link Islamic religiosity to e-book pirates. Based on this explanation, this study aims to obtain empirical evidence of the effect of Islamic religiosity, attitude, and self-efficacy on the intention of accounting students to e-book piracy.

\section{Literature Review and Hypotheses Development}

\section{E-book Piracy}

Digital piracy is the process of illegally duplicating digital goods, documents, audio, video, without asking for legal permission from the copyright holder for any reason other than the purpose of backup (Wulandari, 2014). The digital piracy pattern can be divided into two parts, namely file sharing and hard goods piracy (Deejan, 2009). Hard goods piracy refers to the illegal act of reproducing physical products, such as distributing copies of digital books and reproducing them into physical textbooks. Meanwhile, file sharing refers to the piracy of goods in digital format on the internet, such as illegally uploading digital books or running digital book piracy sites.

Digital books are the contents of printed books in digital form, which has increased in popularity in recent years (Nuwer, 2016). Compared to printed books, digital books offer quick access to book content, in the form of ease in exploring, running, searching, ease of sharing of data, and other benefits (Summerfield et al., 2000). Inevitably, these conveniences lead to digital book piracy (Camarero et al., 2014). Moreover, downloading pirated products on the internet is not difficult and can be completed in less than a minute (Cooper \& Harrison, 2001).

Piracy of digital books is a conscious or unconscious violation of copyright (Camarero et al.., 2014). Digital piracy is defined as the act of copying, downloading, and sharing digital media for any reason without permission from the copyright holder (Gopal et al., 2004; Yu, 2013). Digital piracy is also defined as copying or downloading copyright that is done illegally or without permission (Camarero et al.., 2014).

\section{Hypotheses Development}

Attitude toward a behavior is a thought toward a behavior whether the behavior is beneficial or not (Ajzen, 1991). This thought is related to the assessment of the individual regarding the various benefits or losses that will be obtained if the individual does or does not take the action. Individuals 
will commit digital book piracy if they have positive beliefs about digital book piracy is a beneficial action for that individual, on the other hand, the individual's intention will be small if the individual believes that the act of pirating digital books is wrong. Most studies that use the Theory of Planned Behavior have found that attitude toward the behavior has a large impact on the intention to commit piracy as found by (Arli \& Tjiptono, 2016; Hati et al., 2019; Shah Alam \& Mohamed Sayuti, 2011; Casidy et al.., 2016). So from this explanation, the hypothesis in this study is as follows:

$\mathrm{H1}$ : Attitude positively influences intention to conduct digital book piracy.

Self-efficacy refers to the belief in an individual's ability to act based on his or her needs so he or she achieves that (Bandura, 1998). Self-efficacy is considered as a representation of perceived behavioral control (Bandura, 1982; Yoon, 2011). In TPB, according to Ajzen (1991), the stronger the individual's beliefs are related to certain behaviors, the stronger the individual's perception of control over that behavior. Thus, individuals with higher self-efficacy are more likely to engage in dangerous behavior in the context of digital book piracy. They can commit piracy based on the goals they want to achieve without thinking that the act of piracy can be subject to criminal penalties. Gottfredson and Hirschi (1990) suggest that self-efficacy is served as a determinant of criminal behavior. A similar study was also found by Krueger and Dickson (1994). They found that the higher an individual's self-efficacy, the higher the tendency to take risks. From this explanation, the hypothesis in this study is:

H2: Self-efficacy positively influences intention to conduct digital book piracy.

Self-efficacy is a self-evaluation of capability and control-lability (Gist, 1987). An individual makes decisions based on the reflection of his or her abilities. Self-efficacy can help people from mental stress and strengthen their attitude towards behavior (Wai et al.., 2018). The social cognitive theory states that perceived self-efficacy is influential in fostering attitudes that maintain consistency in the attitude-behavior relationship (Moore \& Homer, 2008; Glasman \& Albarracin, 2006). In the context of this study, individuals with high self-efficacy will have a positive attitude perception towards e-book piracy. Wai et al. (2018) found that a positive effect of self-efficacy on attitude. Based on this explanation, the following hypothesis is proposed:

H3: Self-efficacy positively influences attitude to conduct digital book piracy

Islamic religiosity is an individual belief in Islam that is implemented in the form of practicing Islamic values, such as faith, Islam, and Ihsan (Shihab, 2006). If all of these Islamic values are owned by a person, then he or she is an Islamic religious person who has been serious in implementing Islamic values in daily life. Religiosity has been considered as a significant factor affecting individual values that influence beliefs and behavior (Muslichah \& Sanusi, 2019; Saroglou et al., 2004). People who are very religious, in fact, avoid to engage in unethical behavior (Sanchez et al., 2011; Mellor \& Freeborn, 2011). Studies on the relationship between religiosity and attitudes towards digital piracy have also been conducted in Christianity. A study found that church attendance is positively associated with attitudes against dignity piracy (Fawcett et al., 2013). Based on this explanation, the following is the proposed hypothesis:

H4: Islamic religiosity negatively influences intention to conduct digital book piracy.

H5: Islamic religiosity negatively influences attitude to conduct digital book piracy.

Based on this explanation, the model for this research is displayed on Figure 1. 


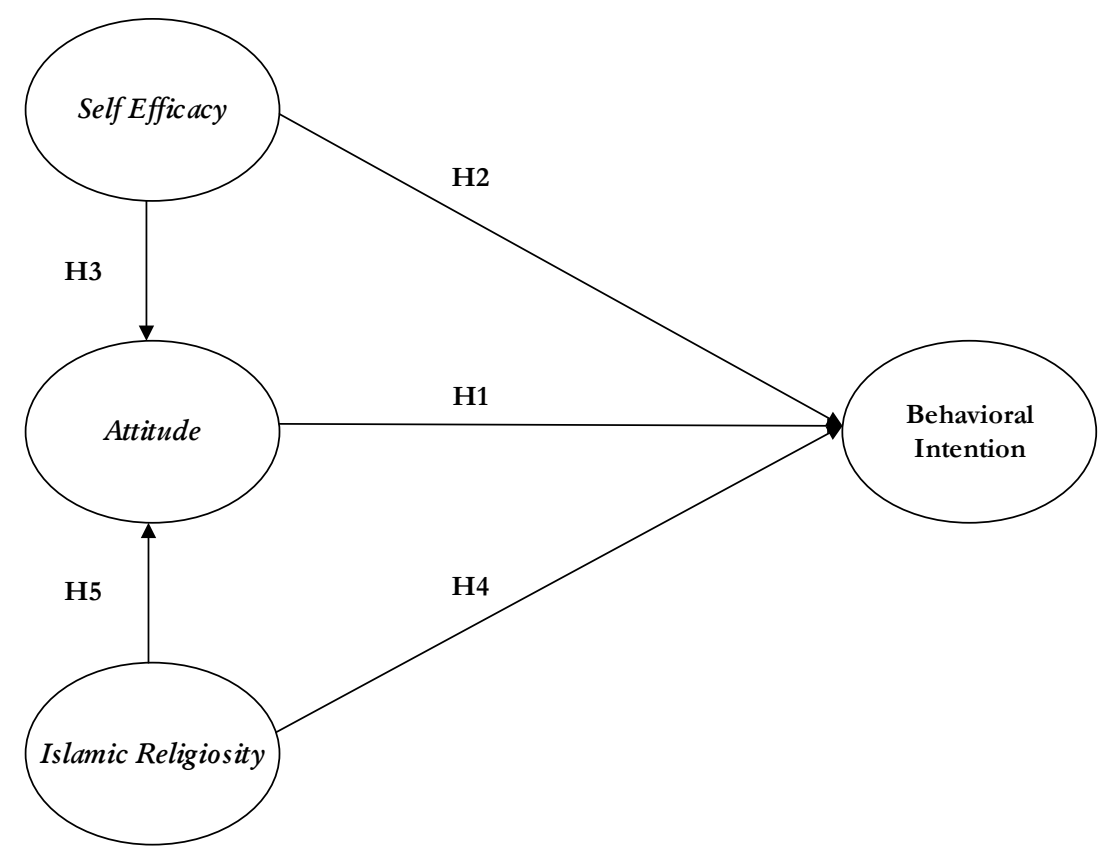

Figure 1. Research Model

\section{Methods}

\section{Sample}

The sampling method in this study was purposive sampling and convenience sampling. Purposive sampling is used by setting certain criteria, where in this study these criteria are students of the accounting study program in Yogyakarta. Meanwhile, convenience sampling is used by distributing questionnaires based on the ease of obtaining them. Researchers took samples only in the Yogyakarta area because thiscity is known as the city of students based on the quality of education, facilities, and the number of campuses which are more than the other cities in Indonesia (Aswin, 2017).

\section{Measurements}

This study used a questionnaire with a Likert scale ranging from 1 "strongly disagree" to 6 "strongly agree". Measurements in each variable in this study were modified from previous studies and adjusted to the context with this study. Attitude is measured by 4 items adopted from Yoon (2011). The self-efficacy variable is measured by 4 items adopted from Hati et al. (2019), and for the Islamic religiosity variable it is measured by 10 items adopted from Barro and McCleary (2003) and Jamal and Sharifuddin (2015). The complete items of measurement for each variable can be seen on Table 2 .

\section{Data Analysis Method}

This study uses data analysis methods using SmartPLS software to test the relationship between interconnected variables run on computer media. Data analysis with SmartPLS includes testing measurement models and structural models (Hair et al.., 2017). The measurement model includes testing the outer loading with outer loading value criteria above 0.6 , convergent vailidity testing by looking at the average variance extracted (AVE) value with the criteria for the AVE value above 0.5 (Hair et al.., 2017). In addition, the measurement model also includes convergent validity testing using cross loading and reliability testing using Cronbach's $\alpha$ and composite reliability (CR) measurements (Hair et al.., 2017). 


\section{Results and Discussions}

\section{Sample Profile}

Table 1 presents in detail the profiles of respondents in this study. In general, female respondents $(68.45 \%)$ dominate the male respondents $(31.55 \%)$. In terms of age, the majority of respondents have an age range between 19 - 20 years $(26.74 \%)$ and 20 - 21 years $(25.13 \%)$. Regarding the study level, the majority of respondents are currently taking undergraduate study $(76.47 \%)$ and diploma $(19.25 \%)$. In terms of monthly allowances, the majority of respondents have a monthly allowance of $1-1.5$ million rupiahs $(31.55 \%)$.

Table 1. Respondent Profile

\begin{tabular}{lcc}
\hline Category & Frequency & Percentage \\
\hline Gender & & \\
Male & 59 & $31.55 \%$ \\
Female & 128 & $68.45 \%$ \\
Age & & \\
$17-18$ & 4 & $2.14 \%$ \\
$18+-19$ & 33 & $17.65 \%$ \\
$19+-20$ & 50 & $26.74 \%$ \\
$20+-21$ & 47 & $25.13 \%$ \\
$21+-22$ & 39 & $20.86 \%$ \\
$22+-23$ & 6 & $3.21 \%$ \\
$23+-24$ & 2 & $1.07 \%$ \\
$24+-25$ & 3 & $1.60 \%$ \\
$25+-26$ & 2 & $1.07 \%$ \\
$27+-28$ & 1 & $0.53 \%$ \\
Study Level & & \\
Diploma & 36 & $19.25 \%$ \\
Bachelor & 143 & $76.47 \%$ \\
Magister & 8 & $4.28 \%$ \\
Monthly Allowance (IDR) & & \\
$<1,000,000$ & 34 & $18.18 \%$ \\
1,000,000-1,500,000 & 59 & $31.55 \%$ \\
1,500,001-2,000,000 & 56 & $29.95 \%$ \\
2,000,001-2,500,000 & 23 & $12.30 \%$ \\
2,500,001-3,000,000 & 10 & $5.35 \%$ \\
3,000,001-3,500,000 & 4 & $2.14 \%$ \\
3,500,001-4,000,000 & 0 & $0.00 \%$ \\
4,000,001-4,500,000 & 1 & $0.53 \%$ \\
\hline
\end{tabular}

\section{Measurement and Structural Model Test}

Table 2 presents the results of the measurement model, including the outer loading, the AVE value for convergent validity testing, the Cronbach's Alpha value, and the composite reliability (CR) for reliability testing. The outer loading test results show that all measurement items score above 0.6 except for IR10 items that has score only 0.1459 . Hence, IR10 is deleted and is not included in the next data analysis. Regarding the convergent validity, it can be seen that the AVE value for each variable is above 0.5 that indicates all variables are valid. Also, the result of reliability test shows that the CA and CR values for each variable are above 0.7 , so it can be concluded that reliability test is fulfilled. 
Tabel 2. Measurement Model Test Result

\begin{tabular}{|c|c|c|c|c|}
\hline Items & Loading & CA & $\mathbf{C R}$ & AVE \\
\hline Attitude (AT) & & 0.9092 & 0.9363 & 0.7863 \\
\hline Digital book piracy is a good thing (AT1) & 0.8711 & & & \\
\hline Digital book piracy is a good idea (AT2) & 0.8980 & & & \\
\hline Digital book piracy is useful (AT3) & 0.8536 & & & \\
\hline I agree with the idea of digital book piracy (AT4) & 0.9228 & & & \\
\hline SelfEfficacy (SE) & & 0.8733 & 0.9105 & 0.7187 \\
\hline Downloading copyright-protected digital books is easy (SE1) & 0.7540 & & & \\
\hline Copying digital books that are copyright protected is easy (SE2) & 0.8618 & & & \\
\hline $\begin{array}{l}\text { It is very easy for me to access pirated digital books from the } \\
\text { internet (SE3) }\end{array}$ & 0.8432 & & & \\
\hline It is very easy for me to use pirated digital books (SE4) & 0.9235 & & & \\
\hline Islamic Religiosity (IR) & & 0.8976 & 0.9189 & 0.5507 \\
\hline I have faith in Allah the Almighty (IR1) & 0.8415 & & & \\
\hline I believe in an afterlife (IR2) & 0.8691 & & & \\
\hline I believe in Heaven and Hell (IR3) & 0.8333 & & & \\
\hline I believe in the Quran (IR4) & 0.8327 & & & \\
\hline I understand the concept of Halal (IR5) & 0.8418 & & & \\
\hline $\begin{array}{l}\text { It is important for me to allocate time for participating in religious } \\
\text { activities (IR6) }\end{array}$ & 0.7395 & & & \\
\hline My religion influences all my decisions in life (IR7) & 0.6329 & & & \\
\hline I took the time to increase my understanding of my religion (IR8) & 0.6843 & & & \\
\hline $\begin{array}{l}\text { Religion is very important to me because it can answer questions } \\
\text { about the meaning of life (IR9) }\end{array}$ & 0.7142 & & & \\
\hline I make financial contributions to my religious organization (IR10) & 0.1459 & & & \\
\hline Intention (IN) & & 0.8755 & 0.9234 & 0.8008 \\
\hline I intend to pirate digital books in the near future (IN1) & 0.9007 & & & \\
\hline If I have the chance, I will pirate digital books (IN2) & 0.9137 & & & \\
\hline I am committed to digital book piracy (IN3) & 0.8695 & & & \\
\hline
\end{tabular}

Table 3. Discriminant Validity Test Result

\begin{tabular}{lrrrr}
\hline & AT & \multicolumn{1}{c}{ IN } & \multicolumn{1}{c}{ IR } & \multicolumn{1}{c}{ SE } \\
\hline AT1 & 0.8711 & 0.5074 & -0.2976 & 0.1641 \\
AT2 & 0.8980 & 0.5926 & -0.3215 & 0.1518 \\
AT3 & 0.8536 & 0.5030 & -0.2219 & 0.2192 \\
AT4 & 0.9228 & 0.6195 & -0.2825 & 0.2556 \\
IN1 & 0.5587 & 0.9007 & -0.3966 & 0.2511 \\
IN2 & 0.6047 & 0.9137 & -0.3520 & 0.2123 \\
IN3 & 0.5255 & 0.8695 & -0.3782 & 0.1217 \\
IR1 & -0.2705 & -0.3745 & 0.8415 & 0.0328 \\
IR2 & -0.2825 & -0.3853 & 0.8690 & 0.0579 \\
IR3 & -0.2149 & -0.3515 & 0.8333 & -0.0627 \\
IR4 & -0.1703 & -0.3757 & 0.8327 & -0.0306 \\
IR5 & -0.3150 & -0.3799 & 0.8419 & 0.0221 \\
IR6 & -0.2247 & -0.2486 & 0.7395 & 0.0151 \\
IR7 & -0.2649 & -0.1909 & 0.6328 & -0.0530 \\
IR8 & -0.2318 & -0.3231 & 0.6845 & -0.0235 \\
IR9 & -0.2533 & -0.2558 & 0.7141 & -0.0939 \\
SE1 & 0.1080 & 0.0949 & 0.0285 & 0.7540 \\
SE2 & 0.1709 & 0.2120 & -0.0367 & 0.8618 \\
SE3 & 0.1334 & 0.1347 & 0.0438 & 0.8432 \\
SE4 & 0.2751 & 0.2414 & -0.0374 & 0.9235 \\
\hline
\end{tabular}


The last measurement model testing is discriminant validity testing which applied cross loading testing. The test results show that the discriminant validity test can be fulfilled because the correlation value of the construct item with the related construct is greater than the other constructs. The complete results of the cross loading test can be seen in Table 3 .

Based on the results of structural model testing, it can be seen that the research model can explain $45.96 \%$ of accounting students' intention to pirate e-books. This model is in the weak category because the value is still below 50\% (Hair et al.., 2017). In addition, this research model is also able to explain $14.93 \%$ attitude. Furthermore, about the results of data analysis regarding hypothesis testing, it shows that all hypotheses are acceptable except for H2. Attitude has a significant positive effect on the intention to pirate e-books (AT - $>$ IN; $\beta=0.5287$; significance $=$ $\mathrm{p}<0.01$ ). This result indicates that $\mathrm{H} 1$ is supported by data. However, $\mathrm{H} 2$ is not supported by data, meaning that self-efficacy does not affect the intention to pirate e-books ( $\mathrm{SE}->\mathrm{IN} ; \beta=0.0987$; not significance). Besides that, self-efficacy has a significant positive effect on attitude (SE -> AT; $\beta=0.2193$; significance $=\mathrm{p}<0.01)$. This indicates that $\mathrm{H} 3$ can be supported by data. Regarding the Islamic religiosity, it can be concluded that Islamic religiosity has a negative effect both on the intention (IR -> IN; $\beta=-0.2497$; significance $=p<0.01$ ), and attitude to pirate e-books (IR -> AT; $\beta=-0.3152$; significance $=\mathrm{p}<0.01$ ). This indicates that $\mathrm{H} 4$ and $\mathrm{H} 5$ are supported. In brief, the result can be seen on Figure 2 .

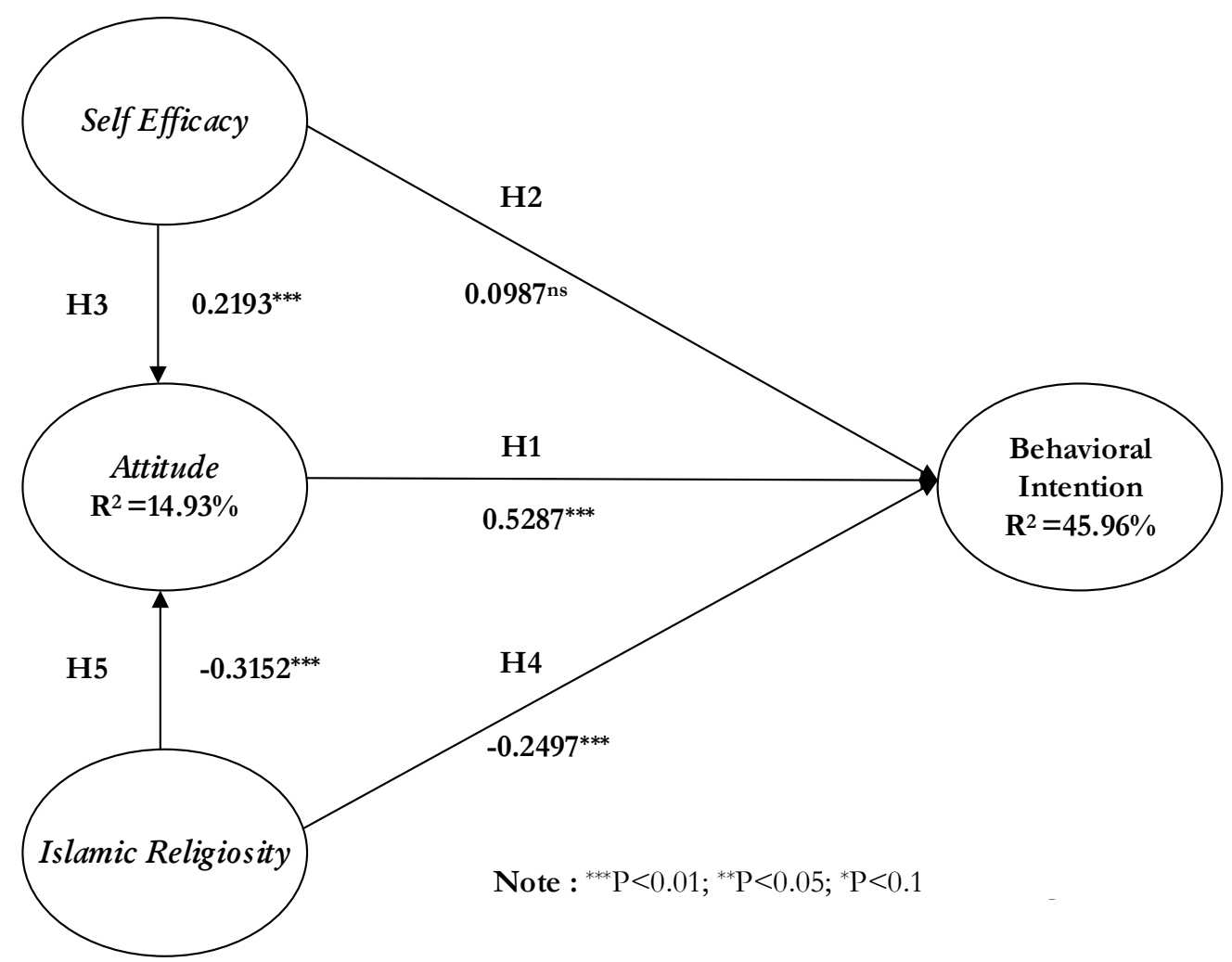

Figure 2: Results of Structural Model

\section{Discussion and Implication}

This study analysed the influence of attitude, Islamic religiosity, and self-efficacy on the intention of accounting students to pirate e-books. The results of data analysis show that this research model is not strong enough because it can explain $45.96 \%$ (less than 50\%) of accounting students' intention to pirate e-books, and $14.94 \%$ of attitudes towards e-book piracy. However, this study finds interesting data analysis results. 
The results explain that attitude has a significant positive effect on accounting students' intention to pirate e-books. This indicates that the higher the perception of accounting students about the benefits of e-book piracy, the accounting students will have a greater intention to pirate e-books. This result aligned with research by Arli and Tjiptono (2016), Hati et al., (2019); Shah Alam and Mohamed Sayuti (2011); Casidy et al., (2016). Therefore, it is important for universities, especially accounting study program lecturers, to be able to form the good attitude of their students towards e-book piracy. The results of data analysis also show that the attitude is the variable that has the strongest influence on the intention of accounting students to commit e-book piracy, so that the role of accounting lecturers to change the attitude of accounting students towards e-book piracy is an important thing to do.

On the other hand, self-efficacy does not have a positive effect on the intention to pirate e-books. But, it has a significant positive effect on attitude. This indicates that accounting students who have the resources and skills to pirate e-books will not have a strong intention to pirate ebooks although they have a higher attitude to do so. The results of this study are in line with Wai et al. (2018) who found that the higher the self-efficacy, the higher the attitude toward behavior. Based on these findings, book publishers need to be able to take advantage of various existing technologies to make e-book piracy more difficult to be done, for example by using digital right management (DRM) (Yoon, 2011).

Lastly, the results of Islamic religiosity on intention also has a significant negative effect. It supports the study by Casidy et al., (2016). This finding indicates that accounting students who obey various Islamic religious provisions have less intention to pirate e-books. Therefore, it is suggested to insert the Islamic values in the process of higher education to prevent accounting students from unethical actions such as e-books pirating. Although it is not the variable that has the greatest influence on intention to pirate e-books, Islamic religiosity has the greatest negative influence on attitude. This finding, furthermore, can strengthen the role of Islamic religiosity in suppressing the intention of accounting students to pirate e-books. Strengthening Islamic religiosity for accounting students is an essential thing for universities, especially to prevent students from e-book piracy behavior that can harm various parties, including writers, auditors, publishers, etc.

\section{Conclusions}

This study examines the effect of attitude, self-efficacy, Islamic religiosity of accounting students on their intention to pirate e-books. From a theoretical point of view, this study supports the result of previous studies regarding the positive effect of attitude and negative influence of Islamic religiosity on the accounting students' intention to pirate e-books. However, this study has some limitations which are expected to be overcame by future studies. There was an Islamic religiosity indicator that has been removed because it is invalid. Future studies are suggested to develop measurements that are more appropriate to the context of Muslim in Indonesia. On the other hand, most of the respondents were undergraduate and diploma students, which represent young generation. This could be a problem in generalizing the research results. In this regard, future research needs to expand the sample by including master and doctoral students.

\section{References}

Ajzen, I. (1991). The theory of planned behavior. Organizational Behavior Human Decision Process, 50(2), 179-211. https://doi.org/10.1016/0749-5978(91)90020-T

Arli, D., \& Tijptono, F. (2016). Consumer digital piracy behaviour among youths: insights from Indonesia. Asia Pacific Journal of Marketing and Logistics, 28(5), 898-922. https://doi.org/10.1108/APJML-11-2015-0163

Aswin. (2017). Kenapa Yogyakarta disebut kota pelajar dan budaya?. Portal Palapa. Retrived from https://www.portalpalapa.com/forum/thread/1049/Kenapa-Yogyakarta-Disebut-Kota- 
Pelajar-dan-Budaya-

Bandura, A. (1982). Self-efficacy mechanism in human agency. American psychologist, 37(2), 122. https://doi.org/10.1037/0003-066X.37.2.122

Bandura, A. (1998). Health promotion from the perspective of social cognitive theory. Psychology and health, 13(4), 623-649. https://doi.org/10.1080/08870449808407422

Bangai, S. (2019). Pembajakan buku membunuh pekerjaan banyak orang. Geotimes. Retrieved from https://geotimes.co.id/komentar/pembajakan-buku-membunuh-pekerjaan-banyakorang/

Banjarnahor, D. (2018). Drama Bank Bukopin: Kartu kredit modifikasi dan rights issue. CNBC Indonesia. Retrieved from https://www.cnbcindonesia.com/market/20180427144303-1712810/drama-bank-bukopin-kartu-kredit-modifikasi-dan-rights-issue

Barro, R. J., \& McCleary, R. M. (2003). Religion and economic growth across countries. American Sociological Review, 68(5), 760-781. https://doi.org/10.2307/1519761

Camarero, C., Antón, C., \& Rodríguez, J. (2014). Technological and ethical antecedents of e-book piracy and price acceptance: Evidence from the Spanish case. Electronic Library, 32(4), 542566. https://doi.org/10.1108/EL-11-2012-0149

Casidy, R., Phau, I., \& Lwin, M. (2016). The role of religious leaders on digital piracy attitude and intention. Journal of Retailing and Consumer Services, 32, 244-252. https://doi.org/10.1016/j.jretconser.2016.04.006

Dejean, S. (2009). What can we learn from empirical studies about piracy?. CESifo Economic Studies, 55(2), 326-352. http://dx.doi.org/ifp006

Fawcett, B. G., Francis, L. J., Henderson, A. J., Robbins, M., \& Linkletter, J. (2013). Religiosity and music copyright theft among Canadian Baptist youth. Journal of Research on Christian Education, 22(2), 153-164. https://doi.org/10.1080/10656219.2013.808974

Gist, M. E. (1987). Self-efficacy: Implications for organizational behavior and human resource management. Academy of management review, 12(3), 472-485. http://dx.doi.org/10.5465/amr.1987.4306562

Glasman, L. R., \& Albarracín, D. (2006). Forming attitudes that predict future behavior: a metaanalysis of the attitude-behavior relation. Psychological bulletin, 132(5), 778-822. http://dx.doi.org/10.1037/0033-2909.132.5.778

Gopal, R. D., Sanders, G. L., Bhattacharjee, S., Agrawal, M., \& Wagner, S. C. (2004). A behavioral model of digital music piracy. Journal of organizational computing and electronic commerce, 14(2), 89-105. https://doi.org/10.1207/s15327744joce1402

Gottfredson, M. R., \& Hirschi, T. (1990). A general theory of crime. Stanford University Press.

Hair, J. F., Hult, G. T. M., Ringle, C. M., \& Sarstedt, M. (2017). A primer on partial least squares structural equation modeling (PLS-SEM) (Second Edi). Los Angeles: Sage Publications.

Hati, S. R. H., Fitriasih, R., \& Safira, A. (2019). E-textbook piracy behavior: An integration of ethics theory, deterrence theory, and theory of planned behavior. Journal of Information, Communication and Ethics in Society, 18(1), 105-123. https://doi.org/10.1108/JICES-11-2018$\underline{0081}$

Jamal, A., \& Sharifuddin, J. (2015). Perceived value and perceived usefulness of halal labeling: The role of religion and culture. Journal of Business Research, 68(5), 933-941. https://doi.org/10.1016/j.jbusres.2014.09.020

Cooper, J., \& Harrison, D. M. (2001). The social organization of audio piracy on the internet. Media, 
Culture \& Society, 23(1), 71-89. https://doi.org/10.1177/016344301023001004

Kozlowski, M. (2018). eBook piracy is on the rise in 2018. Good E-Reader. Retrieved from https://goodereader.com/blog/e- book-news/ebook-piracy-is- on-the-rise-in-2018

Krueger Jr, N., \& Dickson, P. R. (1994). How believing in ourselves increases risk taking: Perceived self-efficacy and opportunity recognition. Decision sciences, 25(3), 385-400. https://doi.org/10.1111/j.1540-5915.1994.tb00810.x

Mellor, J. M., \& Freeborn, B. A. (2011). Religious participation and risky health behaviors among adolescents. Health Economics, 20(10), 1226-1240. https://doi.org/10.1002/hec.1666

Moore, D. J., \& Homer, P. M. (2008). Self-brand connections: The role of attitude strength and autobiographical memory primes. Journal of Business Research, 61(7), 707-714. http://dx.doi.org/10.1016/j.jbusres.2007.09.002

Muslichah, I., \& Sanusi, S. (2019). The effect of religiosity and financial literacy on intention to use Islamic banking products. Asian Journal of Islamic Management, 1(2), 85-92. https://doi.org/10.20885/ajim.vol1.iss2.art2

Nonis, S., \& Swift, C. O. (2001). An examination of the relationship between academic dishonesty and workplace dishonesty: A multicampus investigation. Journal of Education for business, 77(2), 69-77. https://doi.org/10.1080/08832320109599052

Nuwer, R. (2016). If the printed word becomes a thing of the past, it may affect how we think. BBC FUTURE. Retrieved July 30, 2020, from https://www.bbc.com/future/article/20160124-are-paper-books-really-disappearing

Sanchez, Z. M., Opaleye, E. S., Chaves, T. V., Noto, A. R., \& Nappo, S. A. (2011). God forbids or mom disapproves? Religious beliefs that prevent drug use among youth. Journal of adolescent research, 26(5), 591-616. https://doi.org/10.1177/0743558411402337

Saroglou, V., Delpierre, V., \& Dernelle, R. (2004). Values and religiosity: A meta-analysis of studies using Schwartz's model. Personality and individual differences, 37(4), 721-734. https://doi.org/10.1016/j.paid.2003.10.005

Shah Alam, S., \& Mohamed Sayuti, N. (2011). Applying the theory of planned behavior (TPB) in halal food purchasing. International Journal of Commerce and Management, 21(1), 8-20. https://doi.org/10.1108/105692111111111676

Shihab, M. Q. (2006). Menabur pesan Ilahi. Al-Quran dan dinamika kebidupan masyarakat, Jakarta: Lentera Hati.

Sukria, S. K. (2019). Memberangus pembajakan buku. Retrieved from beritagar website: https://beritagar.id/artikel/telatah/memberangus-pembajakan-buku

Summerfield, M., Mandel, C., \& Kantor, P. (2000). The potential for scholarly online books: views from the Columbia University online books evaluation project. Publishing Research Quarterly, 16(3), 39-52. Retrieved from https://www.academia.edu/11759702/The potential for scholarly online books views from the Columbia University Online Books Evaluation Project

Syafina, D. C. (2018). Kasus SNP finance dan pertaruban rusaknya reputasi akuntan publik. Tirto.Id. Retrieved from https://tirto.id/kasus-snp-finance-dan-pertaruhan-rusaknya-reputasiakuntan-publik-c4RT

Syambudi, I. (2019). Konsorsium penerbit yogya lapor polisi lawan pembajakan buku. Tirto.id. Retrieved from https://tirto.id/konsorsium-penerbit-yogya-lapor-polisi-lawanpembajakan-buku-egYZ 
Wai, Y. S., Bojei, J., Osman, S., \& Hashim, N. H. (2018). Perceived self-efficacy and its role in fostering pro-environmental attitude and behaviours. Asian Journal of Business and Accounting, 11(2), 151-186. https://doi.org/10.22452/ajba.vol11 no2.5

Wulandari, H. (2014). Economy and technology as influential factors for digital piracy sustainability: An Indonesian case. Procedia-Social and Behavioral Sciences, 164, 112-117. https://doi.org/10.1016/j.sbspro.2014.11.058

Yoon, C. (2011). Theory of planned behavior and ethics theory in digital piracy: An integrated model. Journal of Business Ethics, 100(3), 405-417. https://doi.org/10.1007/s10551-010$\underline{0687-7}$

Yoon, C. (2012). Digital piracy intention: A comparison of theoretical models. Behaviour and Information Technology, 31(6), 565-576. https://doi.org/10.1080/0144929X.2011.602424

Yu, S. (2013). Digital piracy and stealing: A comparison on criminal propensity. Journal of Criminal $\begin{array}{llll}\text { Justice } & \text { Popular } & \text { Culture, 239-250. }\end{array}$ https://doi.org/10.1017/CBO9781107415324.004 